\title{
LITTERFALL ASSESSEMENT IN A FRAGMENT OF SECONDARY TROPICAL FOREST, IBIÚNA, SP, SOUTHEASTERN BRAZIL ${ }^{1}$
}

\author{
Maurício Lamano Ferreira² e Elizabete Akemi Uchiyama ${ }^{3}$
}

\begin{abstract}
The present study aimed to analyze the production and decomposition of litterfall in a fragment of secondary Atlantic forest in the region of Ibiúna, SP, from April 2012 to March 2013. The litterfall production was estimated by 30 collectors distributed randomly in an area of $1000 \mathrm{~m}^{2}$, where the deposited material was collected every 15 days. The decomposition of litterfall was estimated through the mass loss in the period of study. After collecting, the material was dried in an oven at $65^{\circ} \mathrm{C}$ for seven days to achieve a constant weight. The decomposition constant $k$ was obteined according to Shanks and Oslon (1961) and the time for $50 \%$ and $95 \%$ of decomposition was estimated. It was found a higher litterfall production in October $\left(454.3 \mathrm{~kg} \mathrm{ha}^{-1}\right)$ and lower production in July (164.9 $\left.\mathrm{kg} \mathrm{ha}^{-1}\right)$, with a total amount produced of $3.5 \mathrm{Mg} \mathrm{ha}^{-1}$ year ${ }^{-1}$. A delay of one month in the precipitation and relative humidity showed great influence in the litter production during the study. The decomposition rate $(k)$ was 3.1 and the time to decompose $50 \%$ of the material was estimated in 2 and $1 / 2$ months and for $95 \%$ of the litterfall the time was estimated in 11 and $1 / 2$ months. The production and decomposition values of this work are within the range found in other sites of secondary tropical forests.
\end{abstract}

Keywords: Decomposition; Tropical forest; Plant-soil interaction.

\section{AVALIACCÃO DA SERAPILHEIRA NUM FRAGMENTO DE FLORESTA SECUNDARIA TROPICAL, IBIÚNA, SP, SUDESTE DO BRASIL}

\begin{abstract}
RESUMO-Este estudo teve como objetivo analisar a produção e decomposição de serapilheira em um fragmento de Mata Atlântica secundária na região de Ibiúna, SP, durante abril de 2012 a março de 2013. A produção de serapilheira foi estimada por meio de 30 coletores distribuidos aleatoriamente em uma área de 1.000 $\mathrm{m}^{2}$, onde o material depositado foi coletado quinzenalmente. A decomposição da serapilheira foi estimada por meio da perda de massa no período do estudo. Após a coleta, o material foi seco em forno a $65^{\circ} \mathrm{C}$, durante sete dias, para atingir peso constante. A constante de decomposição (k) foi obtida de acordo com Shanks e Oslon (1961), sendo, em seguida, calculado o tempo para decomposição de $50 \%$ e $95 \%$ do material. Foi encontrada maior produção de serapilheira em outubro $\left(454,3 \mathrm{~kg} \cdot \mathrm{ha^{-1 }}\right)$ e menor em julho (164,9 kg. ha-1), com uma quantidade total produzida de 3,5 $\mathrm{Mg} \cdot \mathrm{ha}^{-1}$.ano ${ }^{-1}$. A precipitação com atraso de um mês e a umidade relativa do ar mostraram grande influência na produção de serapilheira durante o estudo. A taxa de decomposição (k) foi de 3,1 e o tempo de decomposição, de 50 e 95\% do material, estimado em dois meses e meio e 11 meses e meio, respectivamente. Os valores de produção e decomposição deste trabalho estão dentro da faixa encontrada em outros sítios de florestas tropicais secundárias.
\end{abstract}

Palavras-chave: Decomposição; Floresta tropical; Interação solo-planta.

\footnotetext{
${ }^{1}$ Recebido em 11.08.2014 aceito para publicação em 07.07.2015

${ }^{2}$ Universidade Nove de Julho, Programa de Mestrado Acadêmico em Cidade Inteligentes e Sustentáveis (PPG/CIS), São Paulo, SP - Brasil. E-mail: <mauriciolamano@uninove.br>.

${ }^{3}$ Universidade Nove de Julho, Departamento de Ciências da Saúde, São Paulo, SP - Brasil. E-mail: < beteuchiyama@gmail.com>.
}

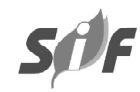




\section{INTRODUCTION}

Litterfall is an extremely important component within the forest ecosystem for nutrient cycling, as well as an indicator of the forest's productive capacity. The knowledge of litterfall amounts in tropical forests is still critical to know and apply biogeochemical models in a climate change scenario (CHAPIN et al., 2002).

Different environments, tree composition, soil type and climate promote different amounts of litterfall production and stock (SANCHEZ et al., 2009; JESUS, et al., 2014), which is determinant for the decomposition rate. All nutrients return occurs primarily through the decomposition which is promoted predominantly by fungi and bacteria, as well as some groups of arthropods. Among the various features of the climate, low temperatures and drought reduce the metabolism of decomposers organism, making their activities reduced (BARBOSA et al., 2010).

It is important to highlight that through the mechanisms of nutrient transference between vegetation and soil some processes of great importance occur for the forest sustainability, where plants drop and uptake resources for growing, once tropical forest soils are normally poor and with low nutrient quality (SILVA et al., 2009) in particular, the Atlantic forest, focus of the present study. The amount of litterfall and its nutrients that are released to the ground by trees will reflect its productive capacity and its potential for environmental recovery, once it is possible to consider that changes will occur in the physical characteristics of the soil (COSTA et al., 2010). Along with the other forest compartments, litterfall contributes to the interception of rainwater through the damping and dispersal of droplet kinetic energy, minimizing the effects of erosion. Tropical forests present an exuberant tree, shrubs and palm flora that depend on the balance of the nutrient cycling (PINTO et al., 2009), which highlights the importance of the decomposition in the system.

The Atlantic forest is fragmented throughout its extension due to an intense history of deforestation and human settlements (LÔBO et al., 2011; LAPOLA et al., 2014). Currently, there are about $8 \%$ of the original size of the forest, whereas if secondary forest areas are included, this value rises to approximately $17 \%$ (RIBEIRO et al., 2009). Many areas have been reforested and other restored, however, little is known about the functioning of these forest types in the Southeast region of the Brazil. Secondary forests may exhibit peculiar characteristics regarding the return of nutrients via litterfall, fact which stands out even more the need to know the functioning of this tropical ecosystem, and even more in areas with important role in the connection of natural landscape.

Considering the region of Ibiúna city is between a preserved area of the Atlantic forest and one of the largest cities in the world, São Paulo, and the region presents some small fragments with important ecological meaning, this study intend to respond the following questions: i) what is the litterfall production in this site of secondary Atlantic forest? ii) what are the most important climatic variables that influence such production? iii) what is the decomposition rate in this forest fragment? Thus, the objective of this study was to evaluate the profile of litterfall production and decomposition in a secondary Atlantic forest fragment, in Ibiúna, SP, and to check the main environmental factors (meteorological) that most influence these biotic variables.

\section{MATERIAL AND METHODS}

\subsection{Study Area}

The study area is located at Ibiúna, just after the end of the metropolitan region of São Paulo (2339'20 "S and $47^{\circ} 13$ ' $31^{\prime \prime} \mathrm{W}$ ). The average elevation at the site is 996 meters a.s.1., with mean air annual temperature about $19{ }^{\circ} \mathrm{C}$, and high relative humidity, oscillating between $60 \%$ and $90 \%$. Located in the physiographic basin of Paranapiacaba, it has a very irregular topography.

\subsection{Litterfall production}

Litterfall was determined using 30 collectors installed randomly in an area of $1000 \mathrm{~m}^{2}(20 \mathrm{~m} \times 50 \mathrm{~m})$ and about 0.5 meters from the soil (SCHUMACHER et al., 2011). The material was collected fortnightly during one year (ARAGÃO et al., 2009; HORA et al., 2008), from April 2012 to March 2013, dried in an oven at $65^{\circ} \mathrm{C}$ (MENEZES et al., 2010), for 7 days or until it reached constant weight. After drying the material, it was weighted in an analytical balance accurate to $0.01 \mathrm{~g}$. The amount of litterfall produced was estimated with the following model, proposed by Menezes et al. (2010):

$$
\mathrm{LP}=\Sigma(\mathrm{MP} \times 10,000) / \mathrm{ca}
$$


where: $\mathrm{LP}=$ litterfall production $\left(\mathrm{kg} \cdot \mathrm{ha}^{-1}\right.$.year $\left.{ }^{-1}\right)$; MP: monthly production of litter $\left(\mathrm{kg} \cdot \mathrm{ha}^{-1}\right)$ and $\mathrm{ca}=$ collector area $\left(\mathrm{m}^{2}\right)$.

\subsection{Decomposition of Litterfall}

After the remaining mass calculation throughout the period, the decomposition constant $(k)$ was obtained according to Shanks and Oslon (1961), with the exponential model: $k=\mathrm{APL} / \mathrm{AAL}$, where: $k=$ constant of decomposition; $\mathrm{APL}=$ annual production of litterfall and $\mathrm{AAL}=$ annual average of accumulated litterfall on the ground. This equation has been used in similar studies (VITAL et al., 2004; CIANCIARUSO et al., 2006; PINTO et al., 2009). The decomposition of $50 \%\left(\mathrm{t}_{0.5}\right)$ and $95 \%\left(\mathrm{t}_{0.05}\right)$ of the material was calculated according to Menezes et al., (2010) following the equation: $\mathrm{T}_{0.5}$ $=\operatorname{Ln}(2) / k$ and $\mathrm{T}_{0.05}=3 / k$, where: $k$ is the constant of decomposition calculated by the previous equation.

\subsection{Statistical Analysis}

Principal component analysis (PCA) was performed to check possible colinearities between the environment variables. Afterward, correlation and multiple regression were made to find out which of the environment factors better explained the input of litterfall on the forest floor.

\section{RESULTS}

The climatic variable that presented the highest oscillation along the experiment was precipitation, with the smallest value verified in September $(22.5 \mathrm{~mm})$ and the highest in December $(268.1 \mathrm{~mm})$. Air temperature remained an average of $19^{\circ} \mathrm{C}$ and the relative humidity and solar radiation and wind speed do not present such variations (Table 1 ).

Principal component analysis (PCA) explained 81\% of the variability of the data, with $45,3 \%$ of the explanation on the axis 1 and $34,8 \%$ on the axis 2 . In general, the analysis showed a higher correlation between the values of potential evapotranspiration, precipitation and water excess with the sample units from the months of December, January, February and March and highest values of global radiation, wind speed and temperature with sample units relative to November and October. The water deficit was more correlated with sample units relative to August and September.

The total production of litterfall in Ibiúna, during the period from April 2012 to March 2013 was estimated at 3,472.1 $\mathrm{kg} \mathrm{ha}^{-1}$ year $^{-1}$ (Figure 4). The deposition of this biomass reached its maximum value of $454,3 \mathrm{~kg}$ $\mathrm{ha}^{-1}$ in October 2012, being the smallest value obtained in January 2013, with $164.9 \mathrm{~kg} \mathrm{ha}^{-1}$.

The litterfall production throughout the year showed no significant correlation with mean air temperature $(\mathrm{r}=0.343, \mathrm{p}=0.275)$ and precipitation $(\mathrm{r}=-0.06, \mathrm{p}=$ $0.840)$, but presented significantly negative correlation with relative humidity $(\mathrm{r}=-057, \mathrm{p}=0.05)$. The wind speed and solar radiation also showed no significant correlation $(\mathrm{r}=0.414, \mathrm{p}=0.181 ; \mathrm{r}=0.196, \mathrm{p}=0.541$, respectively) (Figure 5). In relation to the water storage it was observed a significant negative correlation with litterfall production $(r=-0.864, p=0.0002)$, a fact not observed for real evapotranspiration and water deficit. However, analyzing the correlation of litterfall produced in the current month in response to the rainfall of the previous month we found a strong negative correlation, suggesting that the response of litterfall presented a delay of one month in relation to the rainfall regime in Ibiúna $(\mathrm{r}=-0.741, \mathrm{p}=0.009)$.

Multiple regression showed that water variables were the most important factor that influenced litterfall production $(\mathrm{p}=0.02)$, with emphasis to relative humidity $(p=0.05)$, precipitation $(p=0.039)$ and water storage in the soil $(\mathrm{p}=0.047)$, as shown in the equation below:

$$
\begin{gathered}
\text { LITTERFALL }=-10.623 *(\mathrm{RH})+2.156 *(\mathrm{PREC})- \\
0.487 *(\mathrm{WS})
\end{gathered}
$$

The litterfall decomposition constant $(k)$ was 3.1 . The time to $50 \%$ decomposition of the material $\left(\mathrm{T}_{0.5}\right)$ was approximately 2 and a half months (2.58) and 95\% of the material $\left(\mathrm{T}_{0.05}\right)$ was approximately 11 and a half months (11.28).

Some authors have reported different $\mathrm{k}$ values of those found in this study, which can highlight the diversity of ecosystems in the tropics, however, the results found in this work are within the expected for tropical secondary forest.

\section{DISCUSSION}

This profile of meteorological variables in this study follows a typical pattern for the Southeast region of Brazil, especially for terrestrial ecosystem of the Atlantic forest. It is worth noting that real evapotranspiration, as well as other variables related to the water issues, presents great relevance to local

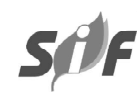

Revista Árvore, Viçosa-MG, v.39, n.5, p.791-799, 2015 
Table 1 - Meteorological variables during the study period. T - average temperature in ${ }^{\circ} \mathrm{C}$; $\mathrm{RH}$ - relative humidity in \%; PREC - precipitation in $\mathrm{mm}$; GR - Global Radiation in $\mathrm{kw} \mathrm{m}^{-2}$ day $^{-1}$; WSP - average wind speed in $\mathrm{m} / \mathrm{s}$; WS water storage in mm; EVT - Real Evapotranspiration in mm; WD - water deficit in mm; and WE - water excess in $\mathrm{mm}$.

Tabela 1 - Variáveis meteorológicas durante o período de estudo. T-temperatura média em ${ }^{\circ} \mathrm{C} ; \mathrm{RH}$ - umidade relativa do ar em \%; PREC - precipitação em mm; GR - Radiação Global em $\mathrm{kW} \mathrm{m}^{-2}$ dia $^{-1}$; WSP - velocidade média de vento em $\mathrm{m} / \mathrm{s}$; WS - armazenamento de água em mm; EVT - evapotranspiração real em mm; WD - déficit hídrico em $\mathrm{mm}$; e WE - excesso hídrico em $\mathrm{mm}$.

\begin{tabular}{|c|c|c|c|c|c|c|c|c|c|}
\hline & $\mathrm{T}$ & $\mathrm{RH}$ & PREC & GR & WSP & WS & EVT & WD & WE \\
\hline apr/12 & 22,4 & 75,8 & 95,3 & 3,6 & 0,9 & 246,0 & 69,0 & 15,0 & 0,0 \\
\hline $\mathrm{may} / 12$ & 18,8 & 76,1 & 90,6 & 3,2 & 0,8 & 427,0 & 56,0 & 1,0 & 0,0 \\
\hline jun/12 & 18,4 & 83,5 & 205,0 & 2,9 & 0,5 & 478,0 & 46,0 & 2,0 & 142,0 \\
\hline jul/12 & 17,2 & 75,7 & 64,4 & 3,2 & 0,8 & 461,0 & 46,0 & 2,0 & 15,0 \\
\hline aug/12 & 19,6 & 66,5 & 0,0 & 3,7 & 0,7 & 293,0 & 41,0 & 25,0 & 0,0 \\
\hline $\mathrm{sep} / 12$ & 21,2 & 65,2 & 22,5 & 3,8 & 1,1 & 107,0 & 17,0 & 70,0 & 0,0 \\
\hline oct $/ 12$ & 23,8 & 66,1 & 106,7 & 4,0 & 1,0 & 85,0 & 86,0 & 26,0 & 0,0 \\
\hline nov/12 & 22,6 & 69,8 & 57,9 & 5,0 & 1,2 & 96,0 & 63,0 & 38,0 & 0,0 \\
\hline $\mathrm{dec} / 12$ & 25,5 & 74,2 & 274,3 & 4,5 & 1,0 & 384,0 & 147,0 & 0,0 & 71,0 \\
\hline jan/13 & 23,0 & 78,4 & 175,1 & 4,5 & 1,1 & 471,0 & 118,0 & 1,0 & 62,0 \\
\hline feb/13 & 24,3 & 73,8 & 105,4 & 5,0 & 0,8 & 440,0 & 120,0 & 9,0 & 15,0 \\
\hline $\operatorname{mar} / 13$ & 23,7 & 69,2 & 130,1 & 4,1 & 1,1 & 458,0 & 102,0 & 4,0 & 47,0 \\
\hline
\end{tabular}

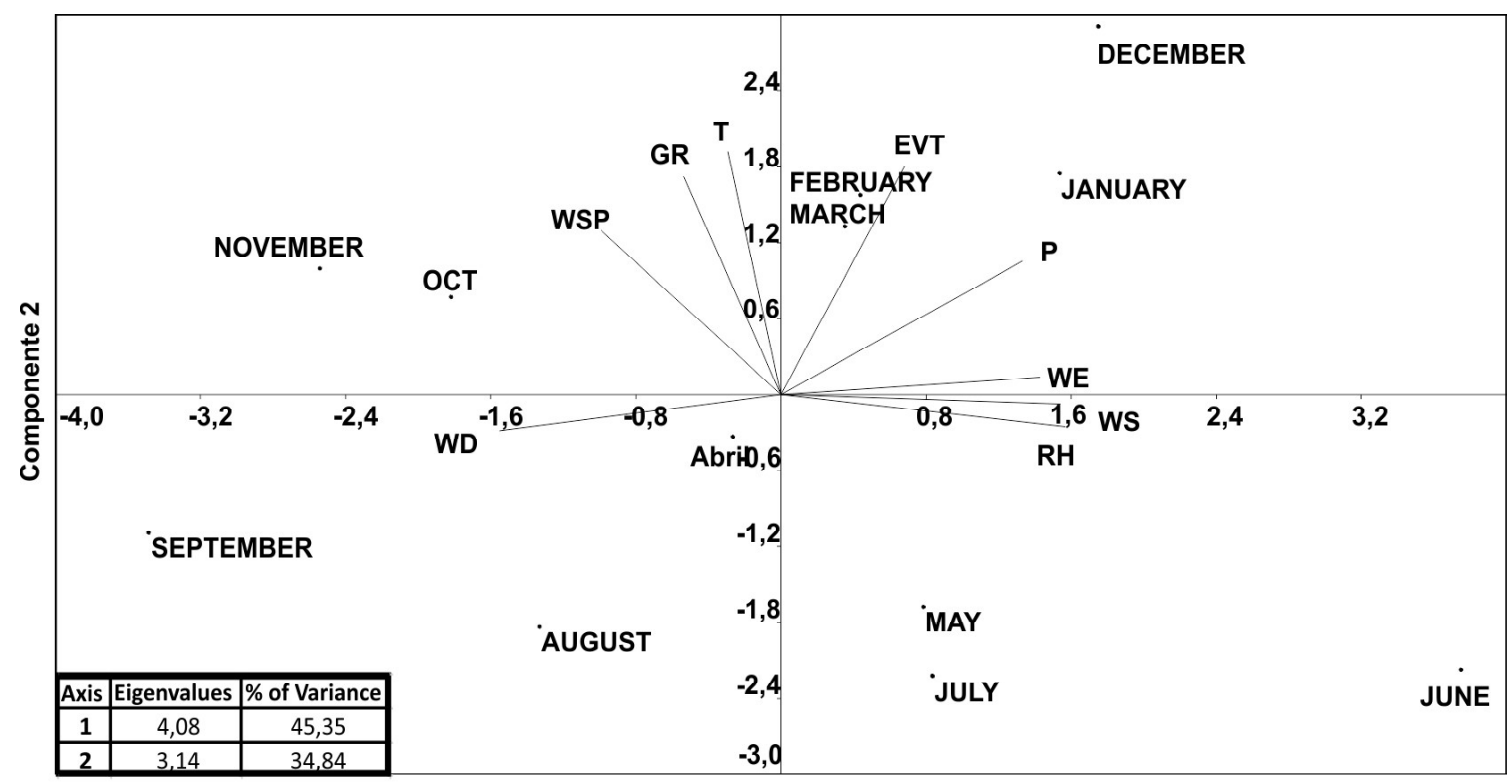

Componente 1

Figure 1 - Main components analysis of meteorological variables in the study area throughout the year. $\mathrm{T}$ - average temperature in ${ }^{\circ} \mathrm{C}$; RH - relative humidity in \%; P - precipitation in $\mathrm{mm} ; \mathrm{GR}$ - Global Radiation in $\mathrm{kw} \mathrm{m}^{-2}$ day $^{-1}$; WSP - average wind speed in $\mathrm{m} / \mathrm{s}$; WS - water storage in $\mathrm{mm}$; EVT - Real Evapotranspiration in $\mathrm{mm}$; WD - water deficit in $\mathrm{mm}$; and WE - water excess in $\mathrm{mm}$.

Figura 1 - Análise de componentes principais das variáveis meteorológicas na área de estudo durante o ano. T- temperatura média em ${ }^{\circ} \mathrm{C} ; \mathrm{RH}$ - umidade relativa do ar em \%; $P$ - precipitação em mm; GR - Radiação Global em $\mathrm{kW} \mathrm{m}^{-2} \mathrm{dia}^{-1}$; $W S P$ - velocidade média de vento em $\mathrm{m} / \mathrm{s}$; WS - armazenamento de água em $\mathrm{mm}$; EVT - evapotranspiração real em mm; WD - déficit hídrico em $\mathrm{mm}$; e WE - excesso hídrico em $\mathrm{mm}$.

Revista Árvore, Viçosa-MG, v.39, n.5, p.791-799, 2015 
plant community dynamics, since water is a physical attribute of the environment with great importance in physiological and ecosystem processes (Table 1).

According to Figure 1, the trend of increased litterfall production from September can be explained by the

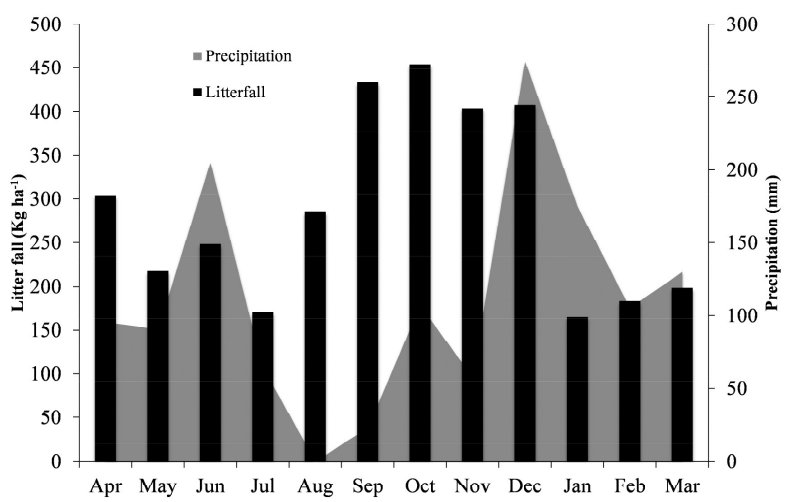

Figure 2 - Monthly average of litterfall production over one year $\left(\mathrm{kg} \mathrm{ha}^{-1}\right)$.

Figura 2 - Média mensal da produção de serapilheira ao longo de um ano $\left(\mathrm{kg} \mathrm{ha}^{-1}\right)$.

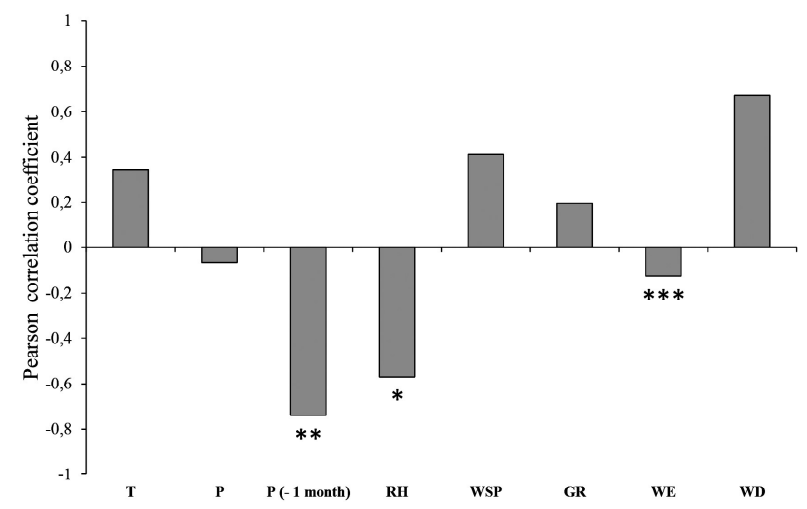

Figure 3 - Pearson correlation factor and meteorological variables. T - mean temperature; $\mathrm{P}$ - accumulated precipitation; $\mathrm{P}$ (-1 month) - precipitation values for the previous month; $\mathrm{RH}$ - relative humidity; WSP - average wind speed; GR - Global Radiation; WE - water excess; and WD - water deficit. Levels of statistical significance: $*(\mathrm{P} \leq 0.05) ; * *(\mathrm{P}$ $<0.01) ; * * *(\mathrm{P}<0.0001)$.

Figura 3 - Fator de correlação de Pearson e variáveis meteorológicas. $T$ - temperatura média; $P$ precipitação acumulada; $P$ (-1 mês) - valores de precipitação do mês anterior; $R H$-umidade relativa do ar: WSP - média de velocidade do vento; $G R$ - radiação global; WE - excesso hídrico; e WD - déficit hídrico. Níveis de significância estatística: $*(P \leq 0,05) ; * *(P<0,01) ; * * *(P<0,0001)$. approaching of the spring season, a fact which could indicate a renewal of leaves and a possible hormonal response to water stress regarding the end of winter for part of the plant community (PAULA et al., 2009), once plants act according to environmental conditions (FERREIRA; DOMINGOS, 2012). Some authors have reported this same trend in tropical forests, such as Menezes et al. (2010) who studied the contribution of litterfall in three distinct characteristics of secondary forests in the Atlantic domain, near the region of Rio de Janeiro and found annual litterfall production ranging from 6,584 to $10,097 \mathrm{~kg} \mathrm{ha}^{-1}$ year $^{-1}$. Pinto et al. (2009) studied the litterfall in two forests with distinct successional features and found a greater production of deciduous material at the end of the dry season and beginning of the rainy season, being the disturbed place the site with the highest value of litterfall production. Pimenta et al. (2011) studied nutrient cycling in a semideciduous forest in southern Brazil and found a greater production of litterfall at the onset of the rainy season. The authors reported a production of about $5341 \mathrm{~kg} \mathrm{ha}^{-1}$ year $^{-1}$, being this value close to that found for tropical forests (2-12 $\mathrm{Mg} \mathrm{ha}^{-1}$ year $\left.^{-1}\right)$ and also close to those found in this study.

In a primary Atlantic forest, Souza Neto et al. (2011) evaluated the litterfall along an altitudinal gradient in the region of Ubatuba, northern region of the São Paulo State and found values of $5.5 ; 7.4$ and $8.4 \mathrm{Mg}$ $\mathrm{ha}^{-1}$ year $^{-1}$ for altitudes of 100,400 and 1000 meters, respectively. It is important to highlight that in a disturbed area with high concentration of atmospheric pollution near São Paulo city, Domingos et al. (1997) found values of high litterfall production in September $\left(847 \mathrm{~kg} \mathrm{ha}^{-1}\right)$ and lowest in July (337 $\left.\mathrm{kg} \mathrm{ha}^{-1}\right)$, with total production estimated of $7007 \mathrm{~kg} \mathrm{ha}^{-1}$ year $^{-1}$. In another environment, Ferreira et al. (2014a) found 5.4 $\mathrm{Mg} \mathrm{ha}^{-1}$ year $^{-1}$ in an urban forest of São Paulo and attributed the changing of wet to dry season as a mechanism that most influenced the production of litterfall.

Interestingly, some climatic variables influenced the litterfall production in this study. Relative humidity and the delay of a month in the rainfall showed inverse and significant relationship with litterfall and this can be explained by the characteristics of the plant community in maintaining the leaves on the trees in response to water availability, since the situation of less water could have stimulated a sign of defense against energy output, such as respiration, being more efficient release higher

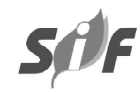

Revista Árvore, Viçosa-MG, v.39, n.5, p.791-799, 2015 
Table 2 - Table with decomposition constant values, time for decomposition of $50 \%$ and $95 \%$ of the litterfall in the literature. Tabela 2 - Tabela com valores de constantes de decomposição, tempo para decomposição de $50 \%$ e $95 \%$ da serapilheira na literatura.

\begin{tabular}{llccc}
\hline Author(s) & Biome & $k$ & Time 50\% (month) & Time 95\% (month) \\
\hline This study & Atlantic forest & 3.1 & 2,58 & 11.28 \\
Fernandes et al. 2006 & Atlantic forest & $0.00194^{*}$ & 11.9 & 22.61 \\
Ferreira et al. 2014 & Atlantic forest & $0,0027^{*}$ & 8,2 & 35,16 \\
Paula et al.. 2009 & Atlantic forest & $0.0032^{*}$ & 7.2 & 13.68 \\
Menezes et al. 2010 & Atlantic forest & $0.0038^{*}$ & 6.06 & 11.51 \\
Pinto et al. 2009 & Atlantic forest & 1.36 & 9 & 17.1 \\
Lopes et al. 2009 & Caatinga & 0.71 & 0.98 & 4.23 \\
Arato et al. 2003 & Cerrado & 0.56 & 1.18 & 2.24 \\
Cianciaruso et al. 2006 & Cerrado & 0.56 & 1.8 & 3.42 \\
\hline
\end{tabular}

*values in $\mathrm{g} \mathrm{g}^{-1}$ day $^{-1}\left(*\right.$ valores em $\mathrm{g} \mathrm{g}^{-1}$ day $\left.^{-1}\right)$.

amounts of leaves between September and December. Theses climatic variables are particularly important for trees ecophysiology, once they also regulate gases changings between plant and atmosphere and thus physiologic process into de plants. Menezes et al. (2010) also found a negative correlation between litterfall production and relative humidity, however, the authors found a positive correlation between the deciduous material and rainfall precipitation. For these authors, the long period with low temperatures and low winter rainfall regimes reflect a high fall of leaves early in the season of spring, when it starts to rain in the region and temperatures increase.

The months of January, February and March of 2013 presented opposite trend of litterfall production and solar radiation, a fact that reinforces the optimization of plants in the photosynthetic process. The temperature did not provide relevant importance in the production of deciduous material in this study. Giácomo et al. (2012) also found no significant correlations with temperature in a study in deciduous tropical Forest, in the region of Minas Gerais. Thus, it is possible that this community responded more efficiently to local water conditions, showing that soil water deficit might trigger a defense mechanism of trees against a possible situation of water stress, thus promoting the fall of leaves as a strategy of economy in the use of water, even if this costs a smaller carbon assimilation through photosynthesis. This might also be a response triggered by hormonal mechanisms (PEZZATTO; WISNIEWSKI, 2006), in which the sensitivity by the lack of water in the soil may trigger physiological, morphological and structural changes. Other papers also reported this water-saving strategy for plant community, as reported in the work de Menezes et al. (2010) and Sanches et al. (2009).

The decomposition rate in this study was quite high for tropical forests, but it is important to highlight that this is a secondary forest with some regeneration characteristics. Golley et al. (1978) found that in tropical forests, the values of $k$ are usually greater than 1 . Souza Neto et al. (2011) found subtly similar values in a site of the Atlantic forest located in the northern coast of São Paulo State, being for the altitudes of 100, 400 and 1000 meters the $k$ values of $2 ; 1.4$ and 1.3 , respectively. For $50 \%$ of litterfall decomposition the authors found 3,5 and 5 months respectively. It is noteworthy that these authors worked in a primary forest and these kinds of environment tend to have slower decomposition rates due to the characteristics of greater system stability. Some others important factors not measured in this work influence the decomposition rate such as the decomposers composition and the soil quality. Ibiúna is in a watershed with accidented topography and poor nutritional soil characteristics, which might contribute for a particular and important environment.

The difference in decomposition rates among rainforests can be attributed to the quality of the material, the type of vegetation covering, fauna activity in the soil and environmental conditions, especially temperature and humidity (ARATO et al., 2003). Ferreira et al. (2014b) found values of nutrient devolution from litterfall to soil in a forest of São Paulo similar to other forests in the Atlantic domain, even the study was carried out in an urban environment, which indicates that the atmospheric pollution of São Paulo could not influence the quality of Ibiúna's forests due to its proximity. Studying 
Cerradão, a biome in Brazil, Cianciaruso et al. (2006) presented $k=0.56$ and the decomposition time of $50 \%$ of material estimated for 1.8 years. Menezes et al. (2010) found half life time of 182 days across forests with different successional states in Pinheiral, RJ. Table 2 demonstrates some studies carried out in tropical forests and their respective $k$ values, time of decomposition of 50 and $95 \%$ of the litterfall.

\section{CONCLUSIONS}

This study showed a profile of litterfall production within a year in a secondary forest of the southeastern region of Brazil, with greater value produced at the beginning of the rainy season. The most important weather variables that influenced such production were related to water issues such as water storage, relative humidity and precipitation. The decomposition rate of litterfall was relatively high and within the expected for secondary forest in tropical sites, once some authors have reported similar values for forests in the State of São Paulo.

\section{ACKNOWLEDGMENTS}

We thank the University Nove de Julho for the support during this study and the comments, suggestions and review of two anonymous referees that contributed to this paper.

\section{REFERENCES}

ARAGÃO, L.E.O.C.; MALHI, Y.; METCALFE, D.B.; SILVA-ESPEJO,3J.E.; JIMÉNEZ, E.; NAVARRETE, D.; ALMEIDA, S.; COSTA, A.C.L.; SALINAS,,N.; PHILLIPS, O.L.; ANDERSON, L.O.; ALVAREZ, E.; BAKER, T.R.; GONCALVEZ. P.H.; HUAMÁN-OVALLE, J.; MAMANI-SOLÓRZANO, M.; MEIR, P.; MONTEAGUDO, A.; PATIÑO, S.; PEÑUELA, M.C.; PRIETO, A.; QUESADA, C.A.; ROZAS-DÁVILA, A.; RUDAS A.; SILVA JR., J.A.; VÁSQUEZ, R. Above-and belowground net primary productivity across ten Amazonian forests on contrasting soils. Biogeosciences, v.6, p.2759-2778, 2009.

ARATO, H.D.; MARTINS, S.V.; FERRARI, S.H.S. Produção e decomposição de serapilheira em um sistema agroflorestal implantado para recuperação de área degradada em Viçosa - MG. Revista Árvore, v.27, n.5, p.715-721, 2003.
BARBOSA, M. D.; MARANGON, L. C.; FELICIANI, A. L. P.; FREIRE, F. J.; DUARTE, G. M. T.; SOUZA, R. N.; SOUZA, J. R. M.; NETO, A. P. M. Carbono e Nitrogênio em Folhedo em Processo de Decomposição em Área de Caatinga. JORNADA DE ENSINO, PESQUISA E EXTENSÃ O-JEPEX, $10^{\circ}$., 2010 , Recife. Recife: Universidade Federal de Pernambuco, 2010.

CIANCIARUSO, M. V.; PIRES, J. S. R.; DELITTI, W. B. C.; SILVA, E. F. L. P. Produção de Serapilheira e Decomposição do Material Foliar em um Cerradão na Estação Ecológica de Jataí, Município de Luiz Antônio, SP, Brasil. Acta Botânica Brasileira, v. 20, n.1, p. 49-59, 2006.

CHAPIN, F.S.; MATSON, P. A.; MOONEY, H. A. Principles of terrestrial ecosystem ecology. New York: Springer Verlag, 2002.

COSTA, C. C. A.; CAMACHO, R. G. V.; MACEDO, I. D.; SILVA, P. C. M. Análise comparativa da produção de serapilheira em fragmentos arbóreos e arbustivos em área de caatinga na FLONA de Açu-RN. Revista Árvore, v. 34, n. 2, p. 259$265,2010$.

DOMINGOS, M.; MORAES, R. M.; VUONO, Y. S.; ANSELMO, C. E. Produção de Serapilheira e Retorno de Nutrientes em um Trecho de Mata Atlântica Secundária, na Reserva Biológica de Paranapiacaba, SP. Revista brasileira de Botânica, v.20, n.1, p. 91-96, 1997.

FERNANDES, M.M; PEREIRA, M.G.; MAGALHÃES, L.M.S.; CRUZ, A.R.; GIÁCOMO, R.G. Aporte e Decomposição de Serapilheira em Áreas de Floresta Secundária, Plantio de Sabiá(Mimosa caesalpiniaefolia Benth.)E Andiroba(Carapa guianensis Aubl.) Na Flora Mário Xavier, RJ. Ciência Florestal, v. 16, n. 2, p. 163-175, 2006.

FERREIRA, M.L.; DOMINGOS, M. Seasonal characterization of antioxidant responses in plants of Ipomoea nilcv. Scarlet O'Hara. Brazilian Journal of Biology, v.72, n.4, p.831-837, 2012.

FERREIRA, M.L.; SILVA, J.L.; PEREIRA, E.E.; LAMANO-FERREIRA, A.P.N. Litter fall production and decomposition in a fragment of secondary

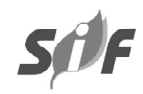

Revista Árvore, Viçosa-MG, v.39, n.5, p.791-799, 2015 
atlantic forest of São Paulo, SP, southeastern Brazil. Revista Árvore, v.38, n.4, p. 591-600, 2014. a

FERREIRA, M.L.; PEREIRA, E.E.; MONTEIRO, P. Ciclagem de nutrientes numa floresta urbana no município de São Paulo, SP. Periódico Técnico e Científico Cidades Verdes, v. 2, p. 1-17, 2014. b

GIÁCOMO, R. G.; PEREIRA, M. G.; MACHADO, D. L. Aporte e decomposição de serapilheira em áreas de cerradão e mata Mesofítica na estação ecológica de Pirapitinga - MG. Ciência

Florestal, v. 22, n. 4, p. 669-680, 2012.

GOLLEY, F.B.; McGINNIS, J.T.; LEMENTS, R.G. Ciclagem de minerais em um ecossistema de floresta tropical úmida. São Paulo: EPU-EdUSP, 1978. 256p.

HORA,R.C.; PRIMAVESI,O.; SOARES,J.J.

Contribuição das folhas de lianas na produção de serapilheira em um fragmento de floresta estacional semidecidual em São Carlos, SP.

Revista Brasileira de Botânica, v.31, n.2, p. 277-285, 2008.

JESUS, P. R.; FILHO H. O. L.; FERREIRA, M. L. Litterfall production in three different sites with different abundance of eucalyptus (Eucalyptus spp.) at the Piqueri Park, SP. Brazilian

Journal of Ecology, v. 01-02, p. 59-65, 2014.

LAPOLA, D. M.; MARTINELLI, L. A.; PERES, C. A.; OMETTO, J. P. H. B.; FERREIRA, M. E.; NOBRE, C. A.; AGUIAR, A. P. D.; BUSTAMENTE, M. M. C.; CARDOSO, M. F.; COSTA, M. H.; JOLY, C.A.; LEITE, C. C.; MOUTINHO, P.; SAMPAIO, G.; STRASSBURG, B. B. N.; VIERIA, I. C. G. Pervasive transition of the brazilian land-use system. Nature Climate Change, v. 4, p. 27-35, 2014.

LÔBO, D.; LEÃO, T.; MELO, F. P. L.; SANTOS, A. M. M.; TABARELLI, M. Forest fragmentation drives atlantic forest of northeastern Brazil to biotic homogenization. Diversity and Distributions, v. 17, p. 287-296, 2011.

LOPES, J.F.B.; ANDRADE, E.M.; LOBATO, F.A.O.; PALÁCIO, H.A.Q.; ARRAES, F.D.D.
Deposição e decomposição de serapilheira em área da cCaatinga. Revista Agro@mbiente On-line, v. 3, n. 2, p. 72-79, 2009.

MENEZES,C.E.G.; PEREIRA, M.G.; CORREIA, M.E.F.; ANJOS, L.H.C.; PAULA, R.R.; SOUZA, M.E. Aporte e Decomposição da Serapilheira e Produção de Biomassa Radicular em Florestas com Diferentes Estágios Sucessionais em Pinheiral, RJ. Ciência Florestal, v. 20, n. 3, p. 439-452, 2010.

PAULA, R.R.; PEREIRA, M.G.; MENEZES,L.F.T. Aporte de nutrientes e decomposição da serrapilheira em três fragmentos florestais periodicamente inundados na ilha da Marambaia, R J. Ciência Florestal, v. 19, n. 2, p. 139$148,2009$.

PEZZATTO, A. W. \& WISNIEWSKI, C. Produção de serrapilheira em diferentes seres sucessionais da Floresta Estacional Semidecidual no oeste do Paraná. Floresta, v. 36, n. 1, p. 111-120, 2006.

PIMENTA,J.A.; ROSSI,L.P.; TOREZAN,J.M.D.; CAVALHEIRO,A.L.; BIANCHINI, E. Produção de serapilheira e ciclagem de nutrientes de um reflorestamento e de uma floresta estacional semidecidual no sul do Brasil. Acta

Botânica Brasilica, v. 25, n.1, p. 53-57. 2011.

PINTO, S.I.C.; MARTINS, S.V.; BARROS, S.F.; DIAS, H.C.T. Ciclagem de nutrientes em dois trechos de floresta estacional semidecidual na Reserva Florestal Mata do Paraíso em Viçosa, MG, Brasil. Revista Árvore, v. 33, n. 4, p. 653-663, 2009.

RIBEIRO, M. C.; METZGER, J. P.; MARTENSEN, A. C.; PONZONI, F. G.; HIROTA, M. M. The Brazilian Atlantic Forest: How much is left, and how is the remaining forest distributed? Implications for conservation. Biological Conservation, v. 142, p. 1141-1153, 2009.

SANCHES, L.; VALENTINI, C.M.A.; BIUDES,M.S.; NOGUEIRA, J.S. Dinâmica sazonal da produção e decomposição de serapilheira em floresta tropical de transição. Revista

Brasileira de Engenharia Agrícola e Ambiental, v.13, n.2, p. 183-189, 2009. 
SHANKS, R.; OLSON, J.S. First year breakdownof leaf litter in Southern Appalachia. Forest Science, v.134, p.194-195, 1961.

SCHUMACHER, M.V.; TRÜBY, P.; MARAFIGA, J.M.; VIERA, M.; SZYMCZAK, D.A. Espécies predominantes na deposição de serapilheira em fragmento de floresta estacional decidual no Rio Grande do Sul. Ciência Florestal, n.3, p. 479-486, 2011

SILVA, R.M.; COSTA, J.M.N.; RUIVO, M.L.P.; COSTA, A.C.L.; ALMEIDA, S.S. Influência de variáveis meteorológicas na produção de liteira na Estação Científica Ferreira Penna, Caxiuanã, Pará. Acta Amazônica, v.39, n.3, p.573-582, 2009.
SOUSA NETO, E.; CARMO, J. B.; KELLER, M.; MARTINS S., C.; ALVES, L. F.; VIEIRA, S. A.; PICCOLO, M. C.; CAMARGO, P.; COUTO, H. T. Z.; JOLY, C. A.; MARTINELLI, L. A. Soil-atmosphere exchange of nitrous oxide, methane and carbono dioxide in a gradient of elevation in the coastal Brazilian Atlantic forest. Biogeosciences, v. 8, p. 733-742, 2011.

VITAL,A.R.T.; GUERRINI,I.A.; FRANKEN,W.K.;FONSECA,R.C.B. Produção de serapilheira e ciclagem de nutrientes de uma floresta estacional semidecidual em zona ripária. Revista Árvore, v. 28, n. 6, p. 793 800, 2004. 